\section{Agroindustrial Science}

Website: http://revistas.unitru.edu.pe/index.php/agroindscience
Escuela de Ingeniería Agroindustrial

Universidad Nacional de Trujillo

\title{
Cassava starch, used as a substitute for aluminum sulfate, is effective in the primary treatment of cloudy water
}

\author{
El almidón de yuca, utilizado como sustituto de sulfato de aluminio, es efectivo en el \\ tratamiento primario de agua turbia
}

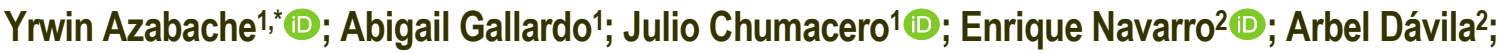 \\ Aníbal Quinteros 2 (1) \\ 1 Facultad de Ecología, Departamento Académico de Ciencias Ambientales y Sanitaria, Universidad Nacional San Martín, \\ Tarapoto, Perú. \\ 2 Facultad de Ingeniería Agroindustrial, Departamento Académico de Ingeniería Agroindustrial, Universidad Nacional San Martín, \\ Tarapoto, Perú.
}

\begin{abstract}
The objective of the present work was to evaluate the effectiveness of cassava starch in the primary treatment of residual waters. The study was carried out using the jar test technique by adding different doses of cassava starch at 1 , 2 and $3 \%$ concentration. the different doses were compared with the optimal primary treatment of aluminum sulfate at a concentration of $1 \%$ that allows a $99.20 \%$ decrease in turbidity, $79,92 \%$ of total dissolved solids, $100 \%$ color and $\mathrm{pH}$. Although pH levels decreased, they were kept within the maximum permissible limit of $(6.5-8.5) \mathrm{pH}$. According to the tests carried out, the water treated with cassava starch is an alternative for the primary treatment of the water of the Shanusi River, since it allows us to comply with the requirements established in the sanitary standards of drinking water quality with regard to color and turbidity.
\end{abstract}

Keywords: Primary treatment; cassava starch; aluminum sulfate; jar test; turbidity.

\section{RESUMEN}

El objetivo del presente trabajo fue evaluar la efectividad del almidón de yuca en el tratamiento primario de aguas residuales. El estudio se llevó a cabo a través la técnica de prueba de jarras mediante la adición de diferentes dosis de almidón de yuca al 1, 2 y $3 \%$ de concentración. Las diferentes dosis fueron comparadas con el tratamiento primario óptimo de sulfato de aluminio a una concentración del $1 \%$ que permite disminuir en $99,20 \%$ de turbidez, $79,92 \%$ de sólidos totales disueltos, $100 \%$ de color; la dosis óptima para almidón de yuca se obtuvo a una concentración del $2 \%$ añadiendo $40 \mathrm{mg} / \mathrm{L}$ a 250 r.p.m mezcla rápida (1,5 minutos), 38 r.p.m mezcla lenta ( 15 minutos), sedimentación (10 minutos), logrando disminuir $96,82 \%$ de turbidez, $25,95 \%$ de sólidos totales disueltos, $73,39 \%$ de color y mantiene el pH dentro del límite máximo permisible de $(6,5-8,5) \mathrm{pH}$. Según los ensayos realizados, el agua tratada con almidón de yuca es una alternativa para el tratamiento primario del agua del río Shanusi, ya que permite cumplir con los requisitos establecidos en las normas sanitarias de calidad de agua potable en lo referente a los parámetros color y turbidez.

Palabras clave: tratamiento primario; almidón de yuca; sulfato de aluminio; prueba de jarras; turbidez.

\section{Introduction}

According to the World Health Organization (2015), $93 \%$ of people who use unimproved water sources live in rural areas. For this reason, for many years, man has tried to give a solution to the lack of access to drinking water through innovative, effective, sustainable, economical, reliable and easy-to-handle techniques that allow waste disposal, risk reduction to health and improve its quality in terms of its appearance, smell, color and taste (Arellano and Guzmán, 2011; Mintz et al., 2001).

Among the simplest water cleaning systems, primary treatment systems can be mentioned, which have the function of preparing the water, cleaning it of all those colloidal particles that generate turbidity from sediments and nutrients, which do not precipitate on their own; and whose dimensions may obstruct or hinder the consequent processes, as well as be vehicles for 
the dispersion of pathogens that affect human health (Joshi and Shju, 2014).

The most common method used to remove particles and a portion of dissolved organic matter is the combination of processes such as coagulation and flocculation followed by sedimentation or filtration. Coagulation is a charge neutralization step that involves conditioning suspended, colloidal and dissolved matter by adding coagulants. Flocculation involves the aggregation of destabilized particles and the formation of larger particles known as sediment flocculation (Mihelcic and Zimmerman, 2012). Being turbidity and color, the indicators of solids suspended in wastewater (Ortiz et al.; 2018).

Among the conventional agents used for primary water treatments are metallic cations (Anastasakis et al., 2009). Aluminum and iron cations being the most used in the purification process. However, studies have shown that they have a detrimental effect on human health (Carrasquero et al., 2019; Trujillo et al., 2014).

In Peru, the use of natural coagulants in water clarification processes is being considered as an appropriate technology for vulnerable sectors, which due to political-economic conditions, cannot access Aluminum Sulfate $\left(\mathrm{Al}_{2}\left(\mathrm{SO}_{4}\right)_{3}\right)$ as primary and traditional coagulant for clarification, it barely satisfies a low percentage of national demand (Rodríguez, 2008).

Among the main natural coagulants used, which are biodegradable, economical and safe due to their compatibility with the environment thanks to the presence of soluble proteins that acts in the process as a natural cationic polyelectrolyte, are Moringa oleifera (Cabrera et al., 2018)., Lefaria cactus, seaweed and cassava starch (Ortiz et al; 2018). According to the aforementioned, natural coagulants have been studied in water clarification processes, as auxiliary agents of aluminum sulfate. However, there are not enough scientific references on the results of functioning in processes where cationic salts have been replaced by natural coagulants.

Cassava (Manihot esculenta Crantz) is a Latin America native plant and it is considered an important source food in many countries around the world. It has been cultivated in various ways in the most diverse climates and soil conditions, and its root shows variations in size, shape and texture. Considered as an important energy source that is also used for animal feed and in the alcohol and gum industry (Inga and López, 2001). A typical ripen root contains: $27 \%$ starch,
$3 \%$ protein, $65 \%$ water, $2 \%$ fiber, $2 \%$ and $3 \%$ other substances $3 \%$ (Jaramillo, 2013).

For the above mentioned, in the present research paper the effectiveness of cassava starch was evaluated as a substitute for aluminum sulfate in the small village of Pampa Hermosa, Yurimaguas district, Alto Amazonas province; supplied with the waters of the Shanusi River, which presents has a high turbidity and color levels, exceeding the values established by the Peruvian Environmental Quality Standards (ECAs); being turbidity a characteristic of water with a high presence of suspended particles whose size varies from thick suspensions to colloids constituting an environmental problem.

\section{Materials and methods \\ Sampling}

The sample was taken from the waters of the Shanusi River, in the small town of Pampa Hermosa - San Martin, to be transferred to the Biology and Chemistry Laboratory of the Faculty of Ecology at San Martin State University where it was analized.

Determination of the initial parameters of the water coming from the Shanusi River

Prior to the tests using the jar test technique, the initial parameters of the sample were determined, information obtained with the following laboratory equipment: turbidimeter (TURBIQUANT 1100 IR), colorimeter (HANNA CHECKER PCU) and multiparameter (OAKTON 600 series).

\section{Test development}

To determine the effective dose of cassava starch, which acts as a coagulant substitute for $1 \%$ aluminum sulfate, a jar test kit was used, in which $500 \mathrm{~mL}$ of sample was placed and different volumes of cassava starch were added $(1,2,3$, 4,5 and $6 \mathrm{~mL}$ as appropriate) at $1 \%, 2 \%$ and $3 \%$. The tests were carried out in three phases:

a) Rapid mixtures with a time of 1.5 minutes of stirring to destabilize the colloidal particles.

b) Slow mixing of 15 minutes of stirring.

c) A sedimentation time of 10 minutes. The mixing rates and sedimentation time used to determine the optimal dose of $1 \%$ aluminum sulfate and $1 \%$ cassava starch, $2 \%$ and $3 \%$ each, are shown in Table 1.

\section{Determination of the final wastewater parameters}

At this stage, the concentrations of the final parameters were measured after the tests, the procedure was performed in the same way and with the same laboratory instruments used in the measurement of the initial concentrations. 
Table 1

Compositions used in coagulating agent mixtures in each test

\begin{tabular}{lccccc}
\hline Test & 1 er & $2^{\text {do }}$ & $3^{\text {er }}$ & $4^{\text {to }}$ & $5^{\text {to }}$ \\
\hline Rapid mixing (r.p.m) & 300 & 250 & 200 & 150 & 100 \\
Slow mixing (r.p.m) & 75 & 63 & 50 & 38 & 25 \\
Sedimentation time (min) & 10 & 10 & 10 & 10 & 10 \\
\hline
\end{tabular}

\section{Results and discussion}

During the first stage of the research, the initial conditions (prior to treatment) of the samples of water collected in the Shanusi River were determined, finding the average turbidity values: (136.67 \pm 7.51 NTU), total dissolved solids (321.5 \pm 57.86$), \mathrm{pH}$ (6.96 \pm 0.38 units) and color (269.67 \pm 17.95 UPC).

The results prove to be in an unfavorable condition positioning them in the Category A-1 (A3) of the Peruvian Environmental Quality Standards (ECAS) (MINAM, 2015). The maximum turbidity values were 100 NTU, total dissolved solids $1000 \mathrm{mg} / \mathrm{L}$, color $100 \mathrm{UPC}$ and $\mathrm{pH}$ should have a value between 6.5 - 8.5.
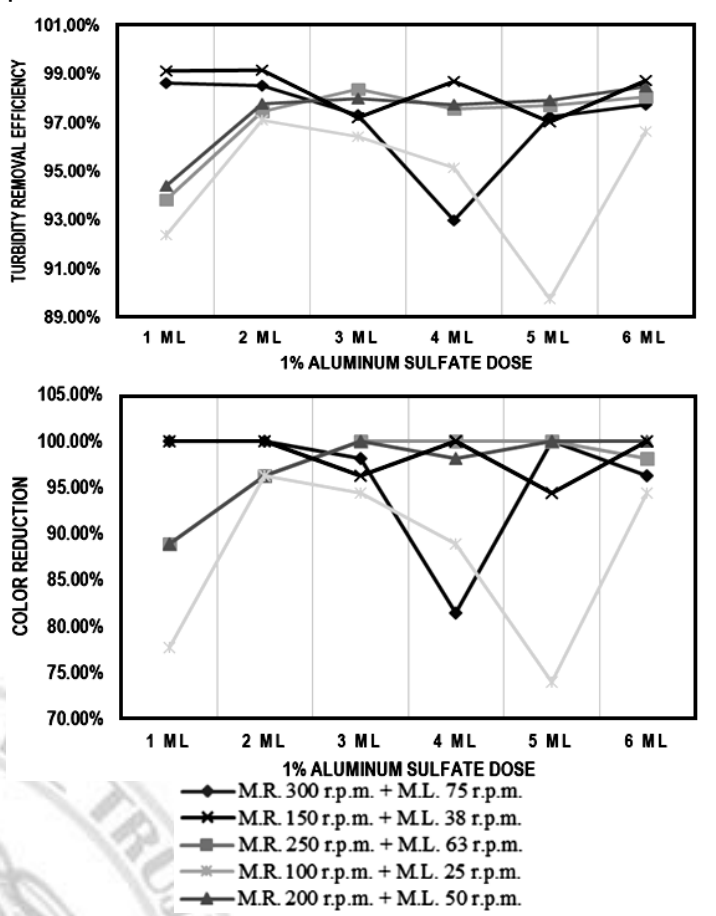

Figure 1. Turbidity removal efficiency and color reduction of the tests with of $1 \%$ aluminum sulfate.

Determination of the optimal coagulant dose and coagulant removal efficiency

Flocculation tests with $\mathrm{Al}_{2}\left(\mathrm{SO}_{4}\right)_{3}$ at $1 \%$

After the analysis of the samples treated with the different tests, it is evident from the analysis of aluminum sulfate in the removal of turbidity, the reduction of total dissolved solids and color in all the tests carried out. Therefore, ir is possible to use doses of $1 \mathrm{ml}$ or more $\mathrm{Al}_{2}\left(\mathrm{SO}_{4}\right)_{3}$ to $1 \%$ to obtain a $90 \%$ decrease in water turbidity (MezaLeones et al., 2018; Asante et al., 2014).

However, because aluminum sulfate a substance harmful to human health (Oliveira et al, 2017), the dose that best meets this criterion and presents better results was the fourth test of the 2 $\mathrm{mL}$ dose of $1 \%$ aluminum sulfate (fast mix 150 r.p.m. and slow mix 38 r.p.m.), which had average turbidity removal values of $99.18 \%(1.12$ NTU), $76.92 \%$ STD removal $(74.21 \mathrm{mg} / \mathrm{L}), \mathrm{pH}$ decrease of $13.79 \%$ (6\%) and $100 \%$ color decrease (UPC). The values found are below the maximum permissible limits established in the Regulation of water quality for human consumption (MINAM, 2015) and have been taken as reference values to determine the effectiveness of cassava starch.
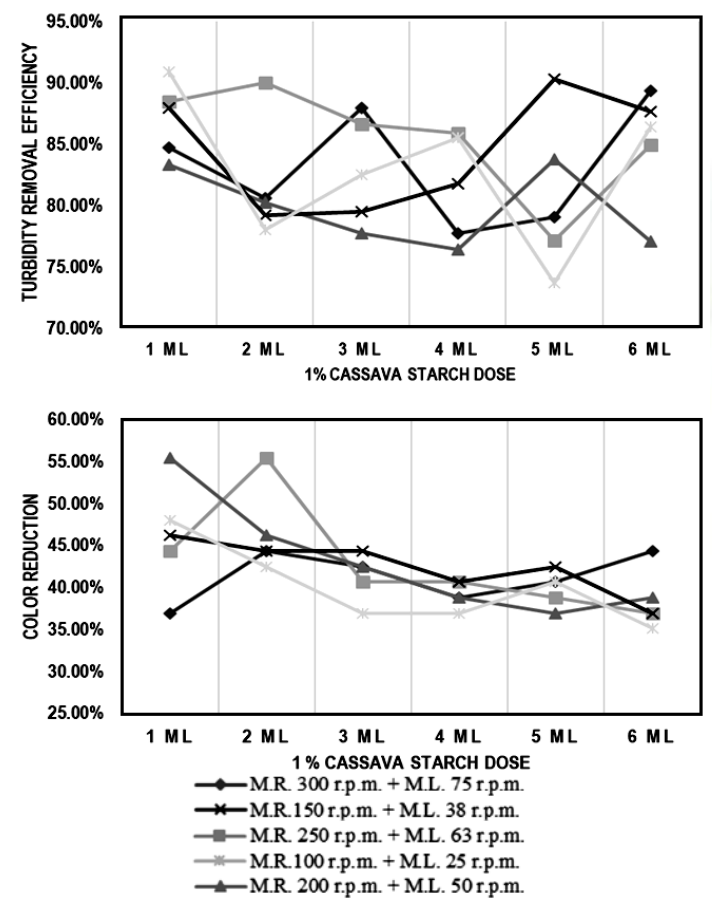

Figure 2. Turbidity removal efficiency and color reduction of the tests with $1 \%$ cassava starch.

\section{Cassava starch flocculation tests at $1 \%$}

As with aluminum sulfate, the five tests described in Table 1 were applied to determine the optimal dose of cassava starch.

From the results observed in Figure 2, in terms of turbidity removal, tests 4 (quick mix 150 r.p.m and slow mix 38 r.p.m) and 5 (quick mix 100 r.p.m and slow mix 25 r.p.m) with doses of $1 \mathrm{~mL}$ and $6 \mathrm{~mL}$ respectively obtained results with removal percentages above $90 \%$. Regarding color removal, removals occurred in the range of $35 \%$ to $55 \%$, a situation that did not allow the 
maximum permissible limits established in the regulation of water quality for human consumption to be met. Similarly, in all the tests the potential of hydrogen and the total dissolved solids had results below the limit of STD 1000 $\mathrm{mg} / \mathrm{L}$ and $\mathrm{pH}(6.5-8.5)$ for all the jars.

\section{Cassava starch flocculation tests at $2 \%$}

The Figure 3 shows the results of turbidity and color removal after primary water treatment of the Shanusi River. The best results were obtained in the second test at $2 \%$ cassava starch a (quick mix 250 r.p.m and slow mix 63 r.p.m.) In jar 1 when adding $1 \mathrm{ml}$ of the solution, with average turbidity removal values of $99.18 \%$ (4.37 NTU), STD removal of $76.92 \%$ (248.8 mg/L), pH decreases of $13.79 \%(7.77 \%)$ and $100 \%$ color decrease (70 UPC), values that are below the maximum permissible limits except for color.
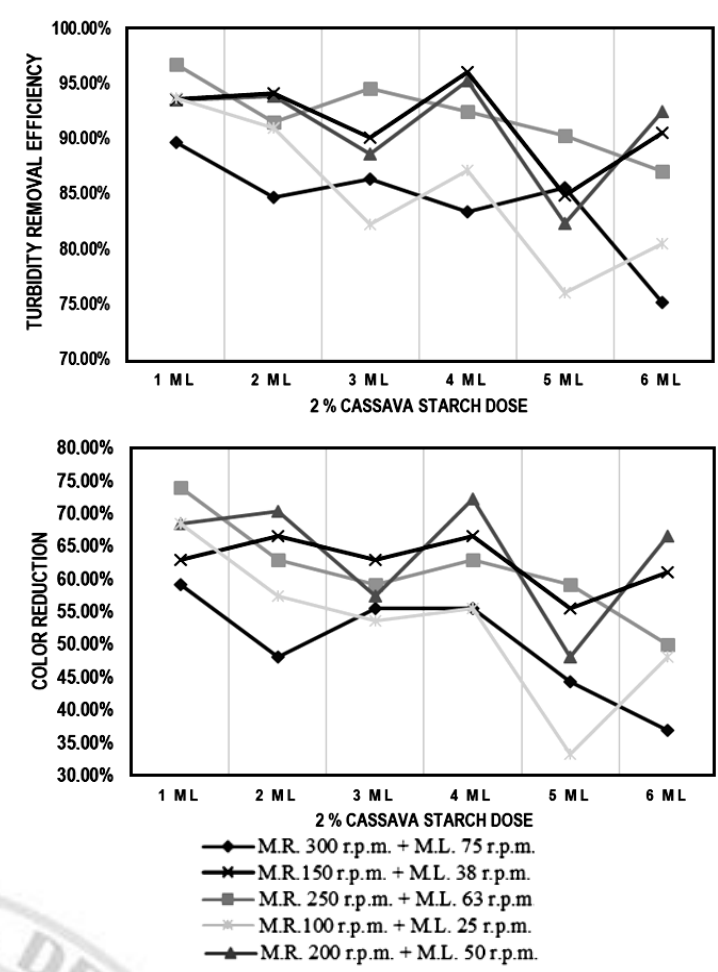

Figure 3. Turbidity removal efficiency and color reduction at $2 \%$ cassava starch dose.

\section{Cassava starch flocculation tests at $3 \%$}

In Figure 4, from the results obtained it follows that in the third test with 3\% cassava starch (quick mix 200 r.p.m and slow mix 50 r.p.m). The best results were obtained in jar 1 by adding 1 $\mathrm{mL}$ of the solution, with average turbidity removal values of $96.52 \%$ (4.75 NTU), STD removal of $0.34 \%$ (320.4 mg/L), pH decrease of $-8.56 \%$ (7.57\%) and color decrease in $68.48 \%$ (85 UPC), values that are below the maximum permissible limits except for color.
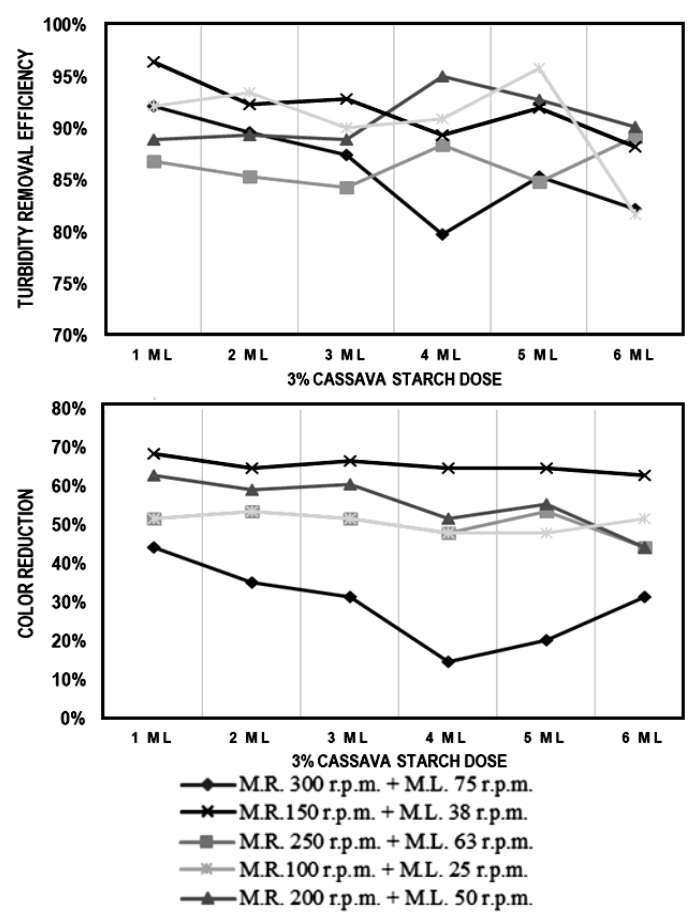

Figure 4. Turbidity removal efficiency and color reduction with $3 \%$ cassava starch dose.

Determination of optimal dose of $\mathrm{Al}_{2}\left(\mathrm{SO}_{4}\right)_{3}$ and cassava starch in the coagulant's removal In this research, for the primary water treatment process of the Shanusi River water, by coagulation, flocculation and sedimentation, cassava starch was used compared to aluminum sulfate, obtaining positive results to decrease turbidity parameters, total dissolved solids, color and $\mathrm{pH}$ maintaining them within the maximum permissible limits, it also helps to neutralize the $\mathrm{pH}$.

In the present research work, it was determined that cassava starch with a dosage of $40 \mathrm{mg} / \mathrm{L}$, reached an acceptable efficiency for the primary water treatment of the Shanusi River, because, despite not reaching the maximum permissible limit of color established in the ECA's (MINSA, 2010 ), it was able to remove $96.82 \%$ turbidity, $25.95 \%$ total dissolved solids, $73.39 \%$ color and maintains the $\mathrm{pH}$ within the maximum permissible limit of $(6.5-8.5) \mathrm{pH}$. This demonstrates the clarifying capacity of cassava starch, and therefore the possibility that it must be used as a coagulation aid; allowing to reduce the amount of aluminum sulfate used in this process (Ortiz et al., 2018).

Finally, it was also shown that aluminum sulfate as a coagulant is efficient at a concentration of $1 \%$ by adding $20 \mathrm{mg} / \mathrm{L}$, with this dosage it is observed that cassava manages to remove turbidity, dissolved total solids, color and regarding $\mathrm{pH}$ within maximum permissible limit of $6.5-8.5$. 


\section{Conclusions}

From the comparison of cassava starch with aluminum sulfate, $2 \%$ cassava starch reached an acceptable efficiency for the water of the Shanusi River, therefore, despite not reaching the maximum permissible limit of color established in DS No. 031-2010-SA, it manages to reduce $96.82 \%$ turbidity, $25.95 \%$ total dissolved solids, $73.39 \%$ color and maintains the $\mathrm{pH}$ within the maximum permissible limit of $(6.5-8.5) \mathrm{pH}$; Aluminum sulfate has had better results at a concentration of $1 \%$, which are below the maximum permissible limit, thus reducing $99.20 \%$ turbidity, $79.92 \%$ of total dissolved solids, $100 \%$ color and $\mathrm{pH}$ although it decreases, keeps it within the maximum allowable limit of 6.5 - 8.5.

\section{ORCID}

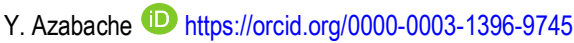

J. Chumacero (D) https://orcid.org/0000-0002-1116-9587

E. Navarro (D) https://orcid.org/0000-0002-9595-8830

A. Quinteros (D) https://orcid.org/0000-0002-4631-5089

\section{References}

Anastasakis, K.; Kalderis, D.; Diamadopoulos, E. 2009. Flocculation behaviour of mallow and okra mucilage in treating wastewater. Desalination 249: 786-791.

Arellano, J.; Guzmán, J. 2011. Ingeniería ambiental. 2da Edición. Alfa Omega. México.

Asante J.; Nasare, I.; Tom-Dery, D.; Ochire-Boadu, K.; Kentil, K. 2014. Nutrient composition of moringa oleifera leaves from two agro ecological zones in Ghana. African Journal of Plant Science 8(1): 65-71.

Cabrera, N.; Simancas, E.; Hernández, J.; 2018. Ensayo de coagulantes naturales extraídos de Ipomoea incarnata y Moringa oleífera en la depuración de aguas residuales industriales en Cartagena de Indias. Prospectiva 16(2): 94-99.

Carrasquero, S.; Martinez, M.; Castro, M.; Díaz, A.; Colina, G. 2019. Remoción de turbidez usando semilla de Tamarindus indica como coagulante en la potabilización de aguas. Revista Base de la Ciencia 4(1): 19-44.

Inga, H.; López, J. 2001. Diversidad de yuca (Manihot esculenta
Crantz) en Jenaro Herrera, Loreto-Perú. Documento técnico nro. 28 IIAP. Iquitos, Perú.

Jaramillo, H. 2013. Almidón de yuca. Editorial Universidad Autonoma de Occidente 13: 35-51.

Joshi, J.; Sahju, 0. 2014. Azadirachta indica leaves as antibacterial treatment on drinking water International Journal of Clinical Nutrition 2(2): 36-40.

MINSA. 2010. Reglamento de la calidad de agua para consumo humano: D.S. N 031-2010-SA / Ministerio de Salud. Dirección General de Salud Ambiental - Lima: Ministerio de Salud; 2011.

MINAM. 2015. Estándares de Calidad Ambiental. DS Nº 015-2015MINAM. Lima - Perú. Available in:

http://www.ana.gob.pe/sites/default/files/normatividad/files/dsndeg-015-2015-minam.pdf

Mintz, E.; Bartram, G.; Lochery, P.; Wegelin, M. 2001. No just a drop in the bucket: expanding access to point-ofuse water treatment systems. American Journal of Public Health 91: 1565-1570.

Mihelcic, J.; Zimmerman, J. 2012. Ingeniería ambiental: Fundamentos, sustentabilidad, diseño. 1ra edición. Alfa omega. México.

World Health Organization. 2015. Progresos en materia de saneamiento y agua potable: informe de actualización 2015 y evaluación del ODM. Available in: https://goo.gl/ifVxKo

Oliveira, V.; Assis, C.; Costa H.; Silva R.; Santos J.; Carvalho L. Jr.; Bezerra, R. 2017. Aluminium sulfate exposure: A set of effects on hydrolases from brain, muscle and digestive tract of juvenile Nile tilapia (Oreochromis niloticus). Comparative Biochemistry and Physiology Part C: Toxicology \& Pharmacology 191: 101108.

Ortiz, V.; López, G.; Torres, C.; Pampillón, L. 2018. Almidón de yuca (Manihot esculenta Crantz) como coadyuvante en la coagulación floculación de aguas residuales domésticas / Cassava Starch (Manihot esculenta Crantz) As a coadyuvant in the coagulation flocculation of domestic wastewater. CIBA Revista Iberoamericana de las Ciencias Biológicas $Y$ Agropecuarias 7(13): 18-46.

Rodríguez, C. 2008. Uso y control del proceso de coagulación en plantas de tratamiento de agua potable. Universidad de sucre Sincelejo. Trabajo de grado para optar el título de ingeniero civil. Universidad de Sucre, Colombia. $97 \mathrm{pp}$.

Trujillo, D.; Duque, L.; Arcila, J.; Rincón, A.; Pacheco, P.; Herrera, 0. 2014. Remoción de turbiedad en agua de una fuente natural mediante coagulación/floculación usando almidón de plátano. Rev. Ion. 27(1): 17-34.

Meza-Leones, M.; Riaños-Donado, K.; Mercado-Martínez, I.; Olibero-Verbel, R.; Jurado-Eraso, M. 2018. Evaluación del poder coagulante del sulfato de aluminio y las semillas de Moringa oleífera en el proceso de clarificación del agua de la ciénaga de Malambo-Atlántico. Revista UIS Ingenierías 17(2): 95-104. 